\title{
O NACIONAL-SOCIALISMO DO GRUPO VALHALLA 88: A CONSTRUÇÃO DE UM MOVIMENTO NAZISTA NO BRASIL
}

\author{
Guilherme Ignácio Franco de Andrade
}

\begin{abstract}
RESUMO
Pretende-se investigar neste artigo as questões raciais presentes na ideologia nacionalsocialista professada pelo grupo Valhalla 88. 0 nazismo, em sua ideologia, tem como elemento principal o arianismo (eugenia), ou seja, a "purificação da raça", pois apenas o "povo escolhido" teria "direito" a governar o mundo por sua "superioridade racial", assim entendida por Adolf Hitler. 0 grupo Valhalla 88 procura disseminar a ideologia nacional-socialista, sua leitura visa manipular e adaptar tais ideias, para que elas se apresentem como alternativa política.
\end{abstract}

Palavras-Chave: Extrema direita. Nacional-socialismo. Neonazismo. Brasil.

\section{THE NATIONAL SOCIALISM OF THE GROUP VALHALLA 88: CONSTRUCTION OF A NAZI MOVEMENT IN BRAZIL}

\begin{abstract}
In this article, the racial issues present in the national-socialist ideology professed by the group Valhalla 88 are investigated. The primary element of Nazi ideology is Aryanism (eugenics), i.e., "race purification," because the "chosen people" have the "right" to rule the world due to their "racial superiority" as understood by Adolf Hitler. The group Valhalla 88 seeks to spread national-socialist ideology, and the group's
\end{abstract}

\footnotetext{
${ }^{1}$ Mestrando no Programa de Pós Graduação em História, Universidade Estadual do Oeste do Paraná - Unioeste, Brasil. Bolsista Capes. guilherme_andrade@hotmail.com
} 
interpretation of this ideology seeks to manipulate and adapt these ideas to provide a political alternative.

Keywords: Far Right; National-socialism; Neo-Nazism; Brazil.

\section{INTRODUÇÃO}

0

aparecimento dos movimentos neonazistas e neofascistas no Brasil segundo a pesquisadora Marcia Regina Costa (1993) em seu livro "Os Carecas do Subúrbio. Caminhos de um nomadismo moderno", se dá no início da década de 1980. 0 nascimento dos primeiros grupos skinheads ${ }^{2}$ em nosso país teve influência dos grupos que surgiram na Inglaterra na década de 1960 e, posteriormente, alguns grupos seriam influenciados pela doutrina nacional-socialista e adotariam posturas baseadas no neonazismo europeu.

Os primeiros pesquisadores sobre o neonazismo no Brasil, como Luiz Roberto Lopes e Paulo Vicentini, Marcia Regina Costa, Helena Salem, acreditam que a estagnação econômica no país e a incerteza política durante o período de redemocratização criaram condições materiais para que os movimentos extremistas, como o neonazismo, pudessem emergir. 0 Brasil, na década de 1980, exibia um cenário semelhante ao da Inglaterra na década de 1960 . 0 país passava por um processo de transformação da classe operária, de crescimento dos movimentos sindicais, em meio à reabertura política, anistia e a redemocratização. 0 clima político em que a sociedade estava envolvida era de instabilidade. Alguns jovens sem perspectiva de futuro e frustrados com a falta de possibilidades e ascensão social, em meio as mudanças do capitalismo (início da globalização e desenvolvimento do neoliberalismo), encontravam consolo em grupos conservadores. Tal situação de descontentamento favorecia 0 crescimento de grupos juvenis voltados a uma ideologia bastante conservadora.

No Brasil, várias pesquisas buscaram apontar os principais motivos para 0 surgimento dos movimentos de extrema direita a partir da década de 1990. De acordo com o historiador Luiz Roberto Lopes (1992), em seu livro "Do Terceiro Reich ao Novo Nazismo", o surgimento dos grupos neonazistas corresponde a meros casos isolados. Seriam grupelhos com pouca expressão política, que não compreendiam o mundo em que viviam e que buscavam, através das manifestações de grupo (como pintar suásticas e brigar com outras gangues), uma forma de chamar atenção e de chocar a sociedade. Nas palavras de Lopes, 0

${ }^{2} 0$ nome faz referência às cabeças raspadas dos integrantes desses grupos. 
neonazismo não tem força suficiente para causar preocupações enquanto movimento reacionário:

Assim como o nazismo em seus tempos áureos não frutificou no Brasil, os neonazistas atuantes hoje em dia também não devem nutrir muitas esperanças de se expandirem. Há quem se impressione com suásticas pintadas em paredes. Mais isso prova uma suposta força dos neonazistas, ou alguma conspiração subterrânea? (LOPES, 1992, p. 146).

Assim, segundo Lopes, no início dos anos 1990, os grupos não apresentavam propostas políticas concretas, não sendo possível a ascensão dos mesmos no Brasil, pois, para ele, na história do país, o fascismo não teve respaldo político:

Há sempre uma parcela de imprevisibilidade no futuro de movimentos como o neonazismo. No Brasil, porém, nada autoriza a pensar que ele vá além do saudosismo de velhos, do entusiasmo confuso de alguns jovens e dos difusos temores que determinados indivíduos nutrem em relação ao judaísmo. Eventualmente, seus integrantes poderão provocar agressões isoladas, restritas a órbita do interesse policial ou judiciário. A direita brasileira, em seu todo, nunca precisou de um fascismo "clássico" para assegurar suas posições (LOPES, 1992, p. 146).

Os neonazistas no Brasil podem ser grupos pequenos, mas, embora sem muita expressão ou programa político concreto, para tomada de poder no país, eles estão se estruturando a cada dia e estão mais organizados atualmente. Nas palavras de Helena Salem também parece não haver motivos para se preocupar em demasia:

Os neonazistas podem estar mais organizados e estruturados em todo 0 mundo do que há uma década, mas ainda assim não passam de pequenos grupos, se comparados com as demais forças políticas nos respectivos países onde atuam. Mas nem por isso são menos perigosos. Sobretudo se levarmos em conta que constituem parte de uma realidade história e filosófica muito mais ampla. Uma realidade de intolerância, de rejeição às diferenças, talvez endêmica a própria história da humanidade (SALEM, 1995, p. 37).

No que diz respeito a ambas as leituras de contexto apresentadas acima, é preciso enfatizar o quanto a história brasileira é permeada por regimes políticos autoritários. Tanto o Estado Novo, como a Ditadura Militar, podem ser caracterizados como regimes bastante autoritários, com alguns elementos concretos do fascismo. Além disso, observamos, na atualidade, que movimentos 
com diretrizes próximas ao ideal neonazista tem se desenvolvido no Brasil. Nesse sentido, podemos datar as boas perspectivas ressaltadas por Lopes (1992) e Salem (1995), na medida em que esses estudos foram realizados no início da década de 1990, quando o cenário mostrava-se menos preocupante. Passados vinte anos em relação a esses primeiros estudos, podemos perceber que os grupos de orientação ideológica neonazista (ainda que não tenham evoluído o suficiente para conseguir cargos políticos) hoje apresentam um rol de questões ideológicas e de propostas mais concretas, além da intensificação de suas atividades e um visível aumento no número de representantes. Tudo isso implica em uma maior complexidade nas formas com que se articulam, abordam seus sujeitos e manifestam-se socialmente.

Vale considerar que não são apenas grupos neonazistas que tem emergido e crescido consideravelmente no contexto brasileiro contemporâneo. A partir do ano 2000, observamos uma intensa radicalização de ideais conservadores, expressos também por outros grupos, como os partidos conservadores cristãos e a volta do integralismo, que hoje apresenta três grupos organizados. Segundo Caldeira Neto (2012), hoje temos três novos grupos integralistas atuando no Brasil; a Frente Integralista Brasileira - FIB; o Movimento Linearista Integralista Brasileiro - MIL-B; e a Ação Integralista Revolucionária ${ }^{3}$.

As produções sobre o neonazismo durante a década de 1990 abordaram mais as questões que envolvem seu surgimento como mero fenômeno político de pequenos grupos isolados, porque as poucas mobilizações e informações dos grupos, no início da década de 1990, não permitiam que se aprofundasse com maior rigor a ideologia dos diferentes grupos, pois se trata de um período de construção e amadurecimento das ideias. Os estudos dos grupos neonazistas no início se pautavam em suas influências, seu comportamento, sua diferença com outros grupos radicais. Não houve uma exploração maior da questão da ideologia em si, em parte por ela se desenvolver a partir dos anos 2000 até os dias atuais.

Os neonazistas no Brasil, no que tange a questão racial, apresentam várias divergências. Alguns grupos, como os Carecas do Subúrbio e skinheads tradicionais, segundo Costa (2000, p. 145), são confundidos com grupos neonazistas, mas, são apenas radicais, ultranacionalistas. A maioria dos grupos rejeita 0 preconceito étnico, embora isso não os exclua da aversão aos homossexuais, comunistas e judeus. Este é o ponto principal que separa

\footnotetext{
${ }^{3}$ Para maior aprofundamento do tema ver em: Caldeira Neto (2011) e Barbosa (2012).
} 
completamente os grupos, para que exista uma análise concreta, não confundindo grupos fascistas e nazistas.

A questão racial é um dos pontos que diferencia o nazismo de outros regimes autoritários. A questão racial, a supremacia da raça ariana durante 0 nazismo, era compreendida como questão primordial. Ela é 0 alicerce para 0 "desenvolvimento" e a "garantia do futuro" da sociedade ariana.

Nos grupos que se afirmam nacionais-socialistas, o racismo está camuflado dentro da ideologia e, mesmo que de forma sutil, é fácil conseguir enxergar nas entrelinhas, quando em alguns pontos não está explícito.

\section{AS TEORIAS RACIAIS USADAS PELO GRUPO BRASILEIRO VALHALLA 88}

Os neonazistas do Valhalla tentam, em primeiro lugar, dizer que 0 nacional-socialismo não é racista e que qualquer abordagem sobre isso é absurda. Deste modo, tal caracterização sobre 0 preconceito dos nazistas seria uma imagem criada pela mídia sionista para desmoralização do movimento (ALGUMAS..., 2012b), criando, assim, uma aversão da população em relação a qualquer ideia de origem nacional-socialista, por serem considerados pelas massas como sendo ignorantes e preconceituosos. 0 conceito de raça desenvolvido pelos neonazistas é baseado nas teorias eugênicas de David Lane, Alfred Rosenberg, Walter Darré ${ }^{4}$ e no livro Mein Kampf, de Hitler. Eles acreditam que a cultura e a superioridade racial são passadas através do DNA e pelo sangue.

Embora 0 conceito de raça esteja ultrapassado e apesar de ser fato amplamente aceito que os diferentes modos e costumes de vida se devem ao ambiente cultural, econômico e social, o Valhalla acredita que a raça seja manifestação do trabalho de milênios da evolução natural e criação da diversidade humana. Nos termos desse discurso, a raça equivaleria à maneira pela qual a natureza se manifesta em nós (RELACIONANDO-SE..., 2012e). No entanto, as principais rotulações dos neonazistas em referência às raças "inferiores" são resultado do preconceito e da marginalização das classes baixas, sempre vinculadas às crises sociais e aos problemas que o Estado não consegue superar, como o aumento da criminalidade, o aumento do desemprego e do controle da

\footnotetext{
${ }^{4}$ Walter Darré e Alfred Rosenberg são dois intelectuais nazistas, precursores das teorias de supremacia racial na Alemanha durante a ascensão do nazismo. Suas ideias apontavam sobre a superioridade dos povos arianos, suas teorias influenciaram o desenvolvimento do projeto racial do nacional-socialismo e também é uma das principais influências nos movimentos neonazistas.
} 
imigração, que é o tema favorito dos neonazistas, ou seja, barrar a migração dos nordestinos e nortistas (RELACIONANDO-SE..., 2012e).

Baseados nas leituras raciais e na discussão sobre as diferenças entre as etnias, os neonazistas acreditam que o fruto de uma relação de miscigenação seria uma praga, um vírus que entraria na corrente sanguínea, que corromperia e destruiria 0 trabalho da seleção natural (RELACIONANDO-SE..., 2012e). Diante disto, para a suposta sobrevivência do grupo e sua "preciosa" raça, é preciso preservar e cultivar a herança dos seus antepassados, histórica e culturalmente.

Os neonazistas acreditam que cumprir com tais serviços de preservação da espécie seria colaborar com a evolução do mundo e da natureza, pautando-se no darwinismo social, de acordo com o qual apenas os mais fortes sobreviveriam (RELACIONANDO-SE..., 2012e). 0 nacional-socialismo supostamente pregaria 0 respeito mútuo entre outros povos, desde que exista respeito à cultura deles. Dessa forma o nacional-socialismo coloca como primordial assegurar a sobrevivência dos povos caucasianos, e para assegurar sua sobrevivência tanto racial quanto cultural, se incentiva o casamento, assim como qualquer outra união, apenas entre seus semelhantes. Ao mesmo tempo, temos provas incontestáveis de que o nazismo em si jamais respeitou qualquer tipo de diferença. Aliás, a diferença causa medo, por isso a sustentação da teoria segregacionista (ARENDT, 1989, p. 84).

0 princípio do sangue é mais uma demonstração das possíveis atrocidades que os novos nazistas prometem. A defesa do sangue e dos genes será mais um capítulo em busca da "limpeza", onde o extermínio de deficientes, doentes, "inferiores" será em nome da "salvação mundial", tudo em busca do "aperfeiçoamento", da eugenia.

Outra característica mantida pelos neonazistas, que está vinculada ao nazismo clássico, é o ódio às minorias étnicas, aos judeus e aos homossexuais, que voltaram a ser os alvos de perseguições. Os homossexuais são considerados aberrações, porque agiriam contra as leis da natureza. A novidade nesses grupos são os ataques contra os nordestinos. Eles se tornam as maiores vítimas do ódio e das agressões, tanto morais quanto físicas. 0 motivo para a adoção da prática de segregação racial está ligada a ordem econômica, ou seja, como no Brasil, por questões históricas, grande parte das classes operárias, dos trabalhadores e pobres são afrodescendentes, nordestinos e miscigenados, por questões de higiene social e da beleza ariana, tais grupos são enquadrados como "sub-raça".

As teorias do darwinismo social (DARWIN, 2000), sobre a evolução natural das espécies, influenciaram as teorias da eugenia. 0 pesquisador Francis Galton 
defendia a tese de que a cultura e o conhecimento eram resultados da transmissão genética e não dos fatores ambientais, sociais e econômicos. Segundo a historiadora Diwan $(2011$, p. 40), a teoria de Galton postulava que a raça ariana possuía o direito de dominar a sociedade, pois seria nas classes dominantes que se concentravam as melhores qualidades genéticas e os socialmente superiores seriam os herdeiros da acumulação cultural depositada nos seus genes (DIWAN, 2011, p. 40). Esse "tesouro genético", aprimorado pela natureza, através de séculos e séculos, aperfeiçoando a seleção natural dos mais "aptos", era o que permitiria aos arianos o controle da sociedade.

A teoria da Hereditariedade se baseava no princípio de que a cultura ancestral estaria depositada no sangue e quando seu primogênito nascesse ele adquiriria a sua cultura através dos genes herdados. Podemos ver que Galton apenas avaliava a questão genética, deixando de lado as implicações econômicas e sociais que existiam. 0 grupo Valhalla 88 , baseado nas teorias da eugenia de Galton, afirma que a herança cultural se deve a nossos antepassados. A origem, os valores e a moral, assim como 0 amor pela terra estariam presentes no sangue e as pessoas que convivessem num mesmo lugar, sob a mesma cultura, se reconheceriam como comunidade (RELACIONANDO-SE..., 2012e), pois esses, segundo o grupo, se emancipariam do sentimento do individualismo, agindo e pensando de forma similar.

Esses pensamentos formaram as bases do nacional-socialismo e foram moldados pela ideia da eugenia e da Supremacia Racial. A eugenia, segundo Goodrick-Clarke (2004), foi a principal arma utilizada pelo nazismo para afirmar que os alemães tinham direito à dominação sobre outras raças. As teorias que influenciaram e fundaram a eugenia são muito mais antigas que o nacionalsocialismo. 0 mito da raça superior não foi criado primeiramente por Adolf Hitler. A política de extermínio não foi uma ideia autêntica do III Reich e assim como as teorias de superioridades raciais, que foram resultantes das pesquisas sobre a evolução das espécies, que partiram de pesquisas e trabalhos supostamente científicos, feitos a partir do século XIX. Assim como o antissemitismo, que existe historicamente desde a idade medieval, tendo suas raízes muito mais profundas e antigas do que propriamente o nazismo.

As novas teorias raciais, utilizadas pelo grupo Valhalla 88, são construídas a partir da década de 1980, principalmente nos Estados Unidos e na Europa. Um dos destaques mencionados pelo grupo no site é o supremacista racial David Lane (1938-2007). Durante sua vida, ele defendeu que a raça branca estaria em extinção e propôs que a raça branca se isolasse do mundo, organizando-se em 
fazendas ou sociedades segregadas (GOODRICK-CLARKE, 2004, p. 33). Suas frases ficaram conhecidas e utilizadas como slogans pelos grupos neonazistas e hoje são referências na forma de identificação dos grupos racistas e neonazistas (GOODRICK-CLARKE, 2004, p. 35). Após suas manifestações ou produções de artigos, os grupos neonazistas utilizavam os números 14/88. 0 número 14 é referência as quatorze palavras de David Lane, "Devemos assegurar a existência de nosso povo e um futuro para as Crianças Brancas", , e 0 número 88 se refere às letras do alfabeto: 8 seria a letra $\mathrm{H}$ e os dois números, 88 , fazem referência a saudação nazista, Heil Hitler.

Em sua história, David Lane apresenta uma longa trajetória nos movimentos radicais. Em sua primeira participação em grupos extremistas, Lane entrou na nova Ku Klux Klan (KKK), no estado do Colorado. Após sua entrada na KKK, David Lane foi além e organizou, em Denver, um grupo seleto de pessoas, que ele nomeou como Cavaleiros da KKK, em 1979. Após perceber que a KKK atuava nas sombras da sociedade, Lane procurou outro grupo onde pudesse levar e divulgar sua luta para sociedade. Foi quando ele entrou no grupo separatista e terrorista Nação Ariana, em 19816. Em um dos congressos da Nação Ariana, Lane conheceu Robert Jay Mathews e, posteriormente, ambos fundaram o grupo terrorista A Ordem, em 1983. Com sua nova organização, Lane passou a escrever sobre sua ideologia supremacista, incitando 0 ódio às minorias étnicas e criticando abertamente o Estado de bem-estar social, alegando que o Estado Norte Americano sustentava os negros e os latinos, deixando os brancos americanos morrer na miséria. Seu novo grupo, A Ordem, após pouco tempo de formação, agia como milícia, extorquindo dinheiro, assaltando propriedades e lojas de armas. Os roubos somaram, aproximadamente, 4 milhões de dólares. Em 1984, Lane foi preso e A Ordem foi proibida de atuar nos EUA. Ele foi acusado do assassinato de duas pessoas, de ameaça de bombas em sinagogas e de formação de grupo terrorista. Durante sua vida na prisão, Lane se dedicou a escrever livros sobre a supremacia Ariana, sobre ciências políticas e sobre a extinção da população branca (GOODRICK-CLARKE, 2004, p. 37).

0 grupo Valhalla 88 apresenta aspectos interessantes relativos a sua ideologia racial. Em um primeiro momento, afirma-se como grupo nacional-

\footnotetext{
${ }^{5}$ Tradução da frase original "We must secure the existence of our people and a future for White Children".

${ }^{6} 0$ Aryan Nation (Nação Ariana) é um grupo separatista Estadunidense, formado em Idaho em 1970, prega a supremacia branca e o isolamento dos caucasianos do resto dos Eua. Considerado como grupo terrorista, a Nação Ariana foi responsável por diversos ataques a comunidades judaicas, homossexuais e políticos democratas.
} 
socialista, procurando desmistificar, segundo eles, qualquer alegação de racismo e xenofobia. Eles procuram expor sua concepção de mundo, como entendimento da sociedade atual, a partir das questões das diferenças raciais, do convívio entre diferentes raças no mesmo espaço geográfico, ou seja, a demonstração do darwinismo social e as afirmações das questões biológicas como sendo verdadeiras, como a questão do desenvolvimento das raças, as diferenças entre as raças, a purificação da raça, enfim, o desenvolvimento da eugenia.

Em segundo lugar, as ideias de David Lane sobre a extinção da raça branca são utilizadas para justificar a própria existência do grupo, sendo, dessa forma, não apenas uma ideologia, mas uma forma de sobrevivência. Com o desenrolar da ideologia, fica evidente que as contradições entre a apresentação do grupo e as justificativas para sua existência e relevância escondem, supostamente, a real intenção do grupo, que é o domínio da raça branca.

Dentre as fontes utilizadas pelos neonazistas para justificar a segregação racial, o principal livro utilizado por eles é o Mein Kampf (Minha Luta), de Adolf Hitler. Nesse livro, Hitler desenvolveu suas teorias políticas, sua concepção de mundo, bem como as questões relativas aos conceitos de povo e de raça. A partir do livro, ele construiu o programa partidário nacional-socialista e expressava posições políticas contrárias à democracia, entendendo-a como uma força desestabilizadora, na medida em que colocava o poder nas mãos das minorias étnicas, que teriam incentivos para enfraquecer e desestabilizar o governo, ou seja, o governo sob controle dos judeus. Para ele, o poder centralizado, forte, sem oposição, com apenas alguns indivíduos comprometidos com a causa, seria a fórmula certa para o desenvolvimento de um país.

0 ponto mais importante para nossa análise do livro escrito por Hitler é a questão da superioridade da raça ariana. A teoria nazista defende que a raça ariana é uma raça-mestra, superior a todas as outras. 0 nazismo, segundo Hitler, defende que uma nação é a máxima criação de uma raça, ou seja, o desempenho de uma nação seria o reflexo do desenvolvimento étnico. Consequentemente, as grandes nações (literalmente, nações grandes) significariam a criação de grandes raças. A teoria, segundo Hitler, propõe que as grandes nações alcançaram tal nível de desenvolvimento devido a seu poderio militar e intelectual e que estes, por sua vez, teriam se originado em culturas racionais e civilizadas, que, por sua vez ainda, seriam criadas por raça com boa saúde (pura), natural (homogênea) e traços agressivos (xenófobo), inteligentes (capitalistas) e corajosos (assassinos). As nações mais fracas seriam então aquelas criadas por raças impuras, isto é, que não apresentam a totalidade de indivíduos de origem única. 


\section{O Site do ValHalla 88}

Um dos principais grupos neonazistas hoje no Brasil é o grupo Valhalla $88^{7}$. Partindo da própria autodefinição veiculada pelo grupo, ele se intitula como sendo nacional-socialista ${ }^{8}$, procurando se apresentar como movimento sério, acadêmico e intelectual, isto é, 0 avesso dos tradicionais grupos skinheads e neonazistas. 0 Valhalla 88 tem pouca militância efetiva, raramente vemos seus membros saírem às ruas para passeatas ou arrumando briga e chamando a atenção da sociedade. 0 site, seus artigos e seu conteúdo não pertencem a uma pessoa física, não existe um autor específico. 0 site é assinado apenas pelo grupo, pois isso garante 0 anonimato e preserva a integridade dos membros. Como eles agem através da internet e em sites hospedados no exterior, conseguem se manter longe dos olhos da justiça brasileira (VALHALLA 88, 2012).

Primeiramente, o nome Valhalla faz referência à mitologia nórdica. Trata-se do lugar onde os guerreiros vikings eram recebidos após terem morrido com honra, em batalha. Na página de abertura do antigo site já podíamos ver claramente a apologia ao nazismo por meio da Fênix segurando a suástica com a seguinte frase: "Não somos os últimos de ontem, somos os primeiros de amanhã",

Seguido de uma introdução onde buscam fazer as apresentações, bem como fornecer as motivações para a criação do movimento, podemos observar que se abre o discurso como a grande maioria dos movimentos neonazistas de hoje fazem, buscando a "verdade", os "inimigos", o "sistema". Esses termos são utilizados para dar embasamento às discussões em torno do revisionismo histórico. A forma de distorcer a verdade e incorporar para si o papel de "justiceiro", como se a realidade estivesse camuflada e as pessoas estivessem cegas, manipuladas por um sistema, a nosso ver, é o modo mais fácil de atacar e desviar o foco das verdadeiras intenções do grupo. 0 começo da apresentação é sempre baseado nas "injustiças" que o nacional-socialismo "sofreria" pelas "manipulações" da mídia.

0 Valhalla 88 se coloca contra o sionismo internacional, contra 0 poder do capital e contra a mentalidade burguesa individualista. Mas nos artigos escritos podemos perceber que esse discurso é contraditório, em primeiro lugar por termos conhecimento que o nacional-socialismo do III Reich foi tão capitalista

\footnotetext{
${ }^{7} 0$ site do grupo Valhalla 88: http://www.nuevorden.net/portugues/valhalla88.html

${ }^{8}$ Referência a ideologia nacional-socialista de Adolf Hitler, diretamente do MeinKampf.

${ }^{9}$ A figura não existe mais no site, mas pertence a meu acervo de fontes sobre 0 grupo.
} 
quanto qualquer outro país europeu da época (com exceção da União Soviética). Desde o começo da trajetória política de Hitler, o crescimento do nacionalsocialismo na Alemanha se deve à parceria com Ernst Hanfstaenge ${ }^{10}$. Foi através de Hanfstaengel que Hitler conheceu Herman Goering e a burguesia alemã. 0 medo do comunismo e uma crise econômica em escala mundial, causada pela queda da Bolsa Americana, contribuíram para que o nazismo conseguisse 0 apoio das elites da região da Baviera e da grande maioria da classe média, principalmente como forma de conter o socialismo na Alemanha (ARENDT, 1989, p. 455).

0 site do grupo tem sido, nos últimos anos, o principal meio de produção e disseminação da ideologia intitulada como nacional-socialista no país. Como se nota em uma dezena de outros sites, seus artigos estão disponíveis para consulta e divulgação da doutrina. Na última década este site já passou por diversos servidores e constantemente é bloqueado pela Polícia Federal. Como de costume, eles hospedam seus sites em servidores internacionais, dificultando o trabalho dos órgãos responsáveis pelo combate ao racismo e apologia ao nazismo. Durante a pesquisa, constatamos que o grupo já possuiu três endereços eletrônicos nos últimos quatro anos e, mesmo assim, apresenta agilidade surpreendente para, em poucos dias, construir um novo site.

0 site é composto por uma introdução, na qual o grupo expõe a necessidade da exposição do artigo Linhas Gerais (LINHAS..., 2012h) que demonstra sua concepção de mundo. Para 0 grupo, 0 artigo nasce com 0 objetivo de, supostamente, esclarecer as pessoas, principalmente aquelas que possuem pouco conhecimento sobre o "verdadeiro" nacional-socialismo. A introdução é uma carta direcionada para quem não tem ou teve a oportunidade de estudar a fundo o nazismo, pois segundo 0 (s) autor(es) da mesma, a versão oficial da História não permite que sejam retiradas conclusões justas e sensatas. A introdução também busca 0 apoio da oposição, dos grupos socialistas e neoliberais, pois estes também teriam sido ludibriados pelo sionismo internacional, apresentando então a tese de que os inimigos também são manipulados pelas distorções que são apresentadas pela "dita" história oficial (LINHAS..., 2012h)

\footnotetext{
${ }^{10}$ Nobre Alemão. Seu pai e seu avô, naturais da Baviera, haviam sido conselheiros da casa real dos Wittelsbach e dos Duques de Saxe-Coburg-Gotha. Foi um dos primeiros a dar assistência econômica para Adolf Hitler no início do partido. Assim como vários outros colaboradores do nacional-socialismo, durante a ascensão de Hitler, rompeu com o partido e fugiu para os EUA.
} 


\section{A IDEOLOGIA E A CONCEPÇÃO DE MUNDO DO VALHALLA 88}

Segundo o grupo Valhalla, o nacional-socialismo foi, durante anos, prejudicado e sistematicamente perseguido pela mídia sionista, pois, de acordo com 0 argumento apresentado, a ideologia defendida por eles libertaria as pessoas das "correntes" da escravidão da sociedade capitalista (PROPAGANDA..., 2012). 0 nacional-socialismo é exposto de tal forma como se o sistema tentasse prejudicar sua imagem, de modo que as informações conhecidas pelas pessoas fossem propagandas para combater a ideologia. Neste contexto, os veículos de comunicação, segundo o autor, seriam as formas encontradas pelos sionistas e pela burguesia capitalista para manipular as massas (PROPAGANDA..., 2012). 0 discurso clama aos leitores o direito de "iluminar" e "esclarecer" a "verdade" sobre o nazismo:

Durante todo século XX nunca foi dado aos Nacional-Socialistas o direito de defesa ou a oportunidade de um debate democrático e justo. Fomos perseguidos em diversos países ao redor do mundo, nossas ideias foram distorcidas para tornar-nos repulsivos, manipularam e falsificaram fatos históricos para impedir as pessoas de caráter de conhecer a verdade (PROPAGANDA..., 2012).

os neonazistas pedem ao mundo o "direito de defesa", a oportunidade de um "debate democrático", tão democrático quanto foi a Alemanha Hitlerista, onde se viram perseguições implacáveis e o genocídio de compatriotas alemães, comunistas, socialistas, homossexuais, deficientes físicos, ciganos e judeus. De modo geral, os adeptos do grupo Valhalla parecem acreditar piamente que a maioria dos crimes contra a humanidade que Hitler e o nacional socialismo foram julgados foram invenções completas ou parciais, o que implicaria em uma condenação injusta para com os defensores do nazismo. De forma a marcar a diferença entre o que é pregado pelos membros deste grupo, faz-se necessário expor o ponto de vista do autor deste artigo. Nesse sentido, é preciso afirmar que acredito que a noção de verdade do grupo consiste numa falsa retórica, que tem a intenção de gerar dúvidas em pessoas que não tem conhecimento sobre os horrores nazistas, procurando gerar confusão de raciocínio, apresentando determinadas informações para tentar gerar desinformação com leviandade.

Os membros do grupo Valhalla 88, em seus textos, tentam colocar em cheque 0 conhecimento histórico das pessoas, ao desencadear um discurso baseado nas possíveis distorções que o nazismo sofreu durante os 1960 anos do pós-guerra. Esse discurso, segundo a antropóloga Adriana Dias (2007, p. 39), está baseado nas obras revisionistas, que procuram negar a responsabilidade do regime Nazista. Do ponto de vista histórico e acadêmico, é pouco provável que 
consigamos aceitar o questionamento dos crimes contra a humanidade cometidos por oficiais nazistas, em vista de este tema ter sido um amplamente debatido e pesquisado, inclusive com base em registros oficiais do próprio regime nazista que documentava burocraticamente os "feitos" contra a população considerada impura e inferior.

A proposta da organização do site do Valhalla 88 é colocar em evidência as principais questões que giram em torno do nacional-socialismo. Esses tópicos funcionam para simplificar a organização do conteúdo a ser tratado. A divisão desses temas tem como propósito, segundo o autor, demonstrar a concepção histórica, as críticas ao capitalismo e a sociedade em geral e também serve para separar o nacional-socialismo de comparações com outras ideologias.

Em linhas gerais, os neonazistas teorizam a destruição do sistema vigente (veremos que seu próprio discurso é contraditório) (0 NACIONAL..., 2012). Para dar maior enfoque à discussão e se desvincular da direita ${ }^{11}$, 0 Valhalla utiliza exemplos como o da Revolução Russa,

Nos tempos da Rússia Czarista, os bolcheviques, por representarem um movimento revolucionário, encaixavam-se à esquerda, porém ao assumir o poder em 1917, deixaram de representar qualquer revolução para se tornar a situação, assim sendo, todo tipo de oposição seria a esquerda, enquanto os marxistas seriam conservadores de seu regime (0 NACIONAL..., 2012).

Segundo o autor, o novo nazismo busca a destruição total do sistema existente. Então, em sua concepção, o nacional-socialismo é de esquerda, embora deixe evidências que a manutenção do capitalismo continua sendo a essência de seu plano político. A grande discussão para 0 crescimento do movimento é que 0 nacional-socialismo parou no tempo e continua a viver na década de 1930. Tendo em vista as mudanças do mundo atual, critica-se o conservadorismo dos grupos de extrema direita diante dos outros partidos, que se desenvolveram e continuaram evoluindo e se adaptando as necessidades de seu tempo. 0 nazismo,

\footnotetext{
${ }^{11}$ A visão de esquerda e direita e o posicionamento político que o Valhalla apresenta refere-se ao surgimento dessa classificação na Assembléia Francesa, no século XVII. De acordo com os termos criados na França, para eles, a direita serviria para definir os reacionários e a esquerda os revolucionários. Evidentemente, esta é uma forma muito simplória de abordar a questão.
} 
para o grupo, deve se focar no nas questões atuais e nos problemas do presente ( 0 NACIONAL..., 2012).

As principais questões apontadas como sendo os problemas do presente tem relação com a globalização e as políticas neoliberais:

Consideramos o Mundo Moderno e a atual "civilização" ocidental como nossos maiores inimigos. Constitui-se de uma sociedade absolutamente materialista e capitalista com uma filosofia burguesa e individualista. Um império construído pelo interesse e pelo egoísmo. Um império não construído para o Povo, não um império cultural ou espiritual, mas um Sistema formado por oligopólios, monopólios, grandes corporações e uma mídia de massa doentia financiada por um Estado imoral e anti-nacional que protege os interesses dos poderosos e do Sionismo (0 NACIONAL..., 2012).

A solução para o grupo é a destruição total do mundo moderno. A modernidade é considerada uma era de decadência. A culpa seria do sistema capitalista, por "exterminar" uma "cultura" (a cultura germânica) de milênios (0 NACIONAL..., 2012). A cultura é concebida aqui a partir cultura germânica que Adolf Hitler tentou empregar, ou seja, o Arianismo e a segregação racial. Soa curiosa a postura dos neonazistas em se afirmarem enquanto defensores de uma cultura que eles pouco conhecem. Eles estão habituados à cultura que foi criada por imigrantes europeus no Brasil. Tanto a cultura, como a língua, portanto, foram modificadas e parte dessa apropriação cultural é utilizada para legitimação de poder ou como prática regionalista, muitas vezes para atrair turistas ou para fins comerciais. Além disso, segundo Herf (1993, p. 217):

Hitler foi o primeiro líder político do século XX a usar amplamente 0 avião. 0 rádio espalhava sua voz e carros velozes aceleravam com ele sobre a Autoban. Suas conversas com os colegas, editadas como as "conversas de mesa", revelam-nos fascinados pelos pormenores da tecnologia militar. Sua aceitação da tecnologia como uma expressão da vontade ariana estava plenamente afinada com a rejeição do iluminismo e das consequências sociais da revolução francesa e das revoluções industriais. 
A cultura pregada e divulgada pelo nacional-socialismo era baseada em uma construção do que deveria ser o "germânico", pois a Alemanha, antes da unificação, não apresentava uma cultura única e homogênea. A mesma abstração do nacional-socialismo pode ser observada no neonazismo no Brasil. o Valhalla 88 procura resgatar uma "cultura" que jamais se consolidou e parte da ideia romântica da superioridade alemã construída no século XIX e que foi retomada durante 0 III Reich.

Durante o governo nacional-socialista, tanto Hitler como Goebbels, procuraram relacionar a cultura germânica com o avanço da tecnologia para demonstração de superioridade intelectual e também desenvolvimento tecnológico das indústrias armamentistas (HERF, 1993, p. 217). No Brasil, pela extensão territorial e, principalmente, pelo enorme número de ciclos imigratórios durante centenas de anos, apresenta-se, em cada pequena região, hábitos e costumes diferentes, sendo muito difícil hoje afirmar uma cultura "brasileira" que defina a maioria da população.

Ao rejeitar a tese de que o nacional-socialismo seria de direita, o grupo tenta se desvencilhar dos outros partidos de direita, com as acusações de serem odiados pela direita, pois estes colaborariam com a burguesia e defenderiam 0 individualismo (PROPAGANDA..., 2012). 0 novo nazismo afirma ser o fim da era de decadência do mundo moderno, para o começo de um império de prosperidade, renovação de um tempo, o Ano Zero:

Abandonamos a mentalidade burguesa e egoísta incompatível com nossa natureza coletivista. Iremos implantar a verdadeira ordem Nacional-Socialista. Somos os únicos que lutam pela edificação da grandeza espiritual do Homem e o colocamos frente aos interesses do capital e do espírito egoísta. Não lutamos só por pão, mas por criatividade e liberdade (SALVE..., 2012).

0 neonazismo prega que as definições de esquerda e direita estão superadas, pois não teriam significado para eles. Esses tipos de rótulos só serviriam para uma pretensa oposição massacrar e continuar a difamar 0 movimento, que se recusaria a participar da "ditadura do dinheiro" e das forças "sionistas internacionais" (SALVE..., 2012). Em busca de reforço, os neonazistas buscam alianças com os inimigos. Eles afirmam que, se for preciso, colaborarão com grupos ideologicamente diferentes, mas que visem igualmente à destruição do sistema (PROPAGANDA..., 2012). 
Para o grupo que pretende destruir a sociedade atual, as exigências são um tanto quanto contraditórias. Como vimos nas questões acima, a abolição do dinheiro obtido sem trabalho e sem esforço é uma crítica à política de bem-estar social e ao assistencialismo dos governos (neo) liberais. Advogam a favor da nacionalização das empresas e a participação nos lucros das grandes empresas. Para um grupo que defende valores coletivos, manter as grandes empresas e querer participação nos lucros demonstra o quão demagogo é o discurso de coletividade. 0 lucro é um dos principais pilares do mundo capitalista, pois ele é o resultado da exploração dos trabalhadores. Manter o lucro, a exploração do trabalho e a mais valia, como qualquer outra instituição baseada nos moldes capitalistas, não vai diminuir as diferenças de classe. Trata-se, assim, mais da tentativa de estabelecer um capitalismo ancorado na figura do Estado, de forma que fosse por este facilmente controlado.

O grupo Valhalla, como se nota a partir de sua doutrina, compreenderia que $o$ bem-estar da comunidade vem antes dos interesses individuais de qualquer outro grupo. Porém, nesse grupo se enquadram apenas os nacionais socialistas, pois a maneira de avaliar a "comunidade", quando apontarmos as questões raciais do grupo, indica que apenas os que são classificados como semelhantes são bem-vindos (PROPAGANDA..., 2012).

0 capitalismo e, principalmente, a globalização, que no entender do grupo seria um fenômeno que marca a "força da usura" e do egoísmo, se situaria como responsável pelos fins das fronteiras nacionais, promovendo a imigração em massa com 0 intuito da diminuição dos custos de mão de obra. Desta forma, o processo de globalização teria provocado a desestabilização dos salários, sem se preocupar com os trabalhadores locais e prejudicando os trabalhadores nacionais (isto é, os considerados como semelhantes), aumentando a criminalidade e implantando culturas que destroem e corrompem a nação como uma praga. A migração não é bem vinda pelos neonazistas, pois eles acreditam que os nordestinos e afrodescendentes são provenientes de uma "raça" diferente, que não conseguem se adaptar e respeitar a cultura branca que eles representam.

0 conceito de raça, segundo Munanga (2003, p. 1-17), não pode ser tomado como um discurso verdadeiro, já que pesquisas das ciências biológicas comprovaram que a humanidade é composta por apenas uma raça, a humana. As diferenças étnicas provém do relacionamento entre diferentes etnias e mesmo assim dois indivíduos da mesma etnia podem, geneticamente, ser completamente diferentes, sendo possível um africano ter mais semelhanças com um dinamarquês do que dois dinamarqueses serem, parecidos. A raça, até o século 
XVII, era um termo para evidenciar a descendência e não era empregado para discriminação ou legitimação da superioridade racial. Conforme Munanga (2003, p. 1-17):

A classificação da humanidade em raças hierarquizadas desembocou numa teoria pseudo-científica, a raciologia, que ganhou muito espaço no início do século XX. Na realidade, apesar da máscara científica, a raciologia tinha um conteúdo mais doutrinário do que científico, pois seu discurso serviu mais para justificar e legitimar os sistemas de dominação racial do que como explicação da variabilidade humana. Gradativamente, os conteúdos dessa doutrina chamada ciência, começaram a sair dos círculos intelectuais e acadêmicos para se difundir no tecido social das populações ocidentais dominantes. Depois foram recuperados pelos nacionalismos nascentes como o nazismo para legitimar as exterminações que causaram à humanidade durante a Segunda guerra mundial.

o grupo Valhalla ataca o sionismo internacional, incriminando a especulação financeira como mecanismo de exploração sem nenhum tipo de contribuição para a sociedade, apenas como sanguessugas das riquezas naturais. 0 nacional-socialismo acredita que 0 patrão honesto e 0 empregado podem conviver e trabalhar com respeito mútuo, em um ambiente saudável e equilibrado. Aqui nos parece emergir mais uma das contradições do discurso do Valhalla, pois defendem a destruição da "ordem atual", mas acreditam numa "sociedade sem conflitos", na harmonia entre patrão e empregado. Isto remete diretamente aos ideais do nazifascismo, nos quais o Estado se situaria acima dos conflitos de classe, de modo a regulamentá-los.

Segundo o manifesto do grupo, o equilíbrio não pode existir enquanto a forma de produção capitalista existir, não nesses termos em que conhecemos, ou seja, enquanto o tempo das máquinas e a produção forem mais importantes que as condições dos trabalhadores. Os neonazistas criticam o marxismo pela sua negação dos conceitos de cultura e de "raça" como identidades imutáveis, substituindo-as pela classe social. Eles julgam que a solidariedade internacional classista não existe de fato, na medida em que o trabalhador nunca teria sido internacionalista, mas, antes, um "patriota". Os internacionalistas, de acordo com o discurso nacional-socialista, são os banqueiros, os empresários, aqueles que não possuem senso de pátria e nação. 
Enquanto o grupo tenta articular sua preocupação (se podemos chamar assim) em relação aos trabalhadores, ao mesmo tempo nega sua liberdade. Assim como Hitler discursou em busca de apoio das classes operárias, os neonazistas se esforçam para tentar atrair os trabalhadores para a causa. 0 erro permanece no momento em que a dita revolução é apenas mais uma utopia para cegar os olhos da população, na medida em que ela vem camuflada por trás de interesses tão burgueses quanto 0 verdadeiro nacional-socialismo alemão. Vale lembrar, segundo Arendt (1989), que a classe média e a elite industrial foram as maiores beneficiadas durante 0 III Reich. Deste modo, a despeito da sua afirmação como socialista e representante dos trabalhadores, o grupo tenta legitimar o trabalho como bem coletivo e como benefício para a posteridade,

0 fator determinante é o caráter, a Honra, o trabalho, a força de vontade individual, e não a conta bancária. Já se passou o tempo em que toleraremos que os grandes chefes, que os detentores do capital tenham o destino de nossas vidas em suas mãos. 0 Nacional-Socialismo é a rebelião do Homem contra o poder do dinheiro. 0 Nacional-Socialismo é a verdadeira voz da classe operária! 0 NacionalSocialismo é socialista! (PROPAGANDA..., 2012).

É evidente a mistura entre ideologias que existe dentro do grupo. Faz referências às ideias socialistas, mas mantém noções próprias do capitalismo e do liberalismo econômico. As afirmações contra 0 capitalismo, em benefício da coletividade, as propostas de revolução e destruição do mundo moderno se confundem dentro do próprio discurso e da manutenção da estrutura capitalista. Ao mesmo tempo prega a positividade do trabalho, ao mencionar o patrão honesto e 0 trabalhador laborioso, ambos podendo conviver em respeito mútuo.

\section{O PAPEL DO REVISIONISMO HISTÓRICO}

A negação do Holocausto é a principal arma para o neonazismo. É através dela que se busca camuflar as atrocidades nazistas, que se tentar gerar, mesmo que por algum tempo, uma dúvida na cabeça das pessoas. Negar os crimes é um jeito de aliviar a consciência. Afinal, que tipo de pessoa consegue adorar uma ideologia que prega a destruição do mundo, em que a simples cor da pele ou a cor dos olhos seja pré-requisito para o extermínio?

Como já citado anteriormente, o revisionismo histórico é utilizado para dar base à ideologia neonazista. Segundo o grupo Valhalla, o Holocausto teria sido uma invenção que equivaleria a um instrumento que o sionismo internacional e os grupos capitalistas encontraram para influenciar a opinião pública contra 0 
movimento nacional-socialista. Conforme tal discurso, através de livros, filmes, datas e memoriais, o Holocausto seria utilizado como arma para difundir "mentiras" contra a Alemanha nazista. Para o grupo, os historiadores são responsáveis pela propaganda contrária ao nacional-socialismo, pois os fatos históricos não teriam sido investigados corretamente. Para ele, os historiadores de influência marxista seriam tendenciosos e trabalhariam como máquinas publicitárias. Nas palavras do grupo: "Tratam a História como uma ciência exata sem permitir ao menos uma resposta ou defesa dos acusados, e quando esta ocorre, não são divulgadas por medo do lobby Sionista." (PROPAGANDA..., 2012).

0 objetivo da História não é apenas o de narrar fatos passados, mas buscar suas origens e suas consequências. A História é a ciência que estuda o passado das sociedades humanas, buscando resgatar e compreender suas realizações econômicas, sociais, políticas, culturais e cada historiador tem seus questionamentos e motivações que o levam a pesquisa e investigação dos processos históricos. 0 estudo do passado humano permite-nos conhecer as motivações e os efeitos das transformações pelas quais passou a humanidade e fornece elementos que ajudam a explicar as sociedades atuais. Ela é a ciência que estuda os acontecimentos do passado da humanidade, com o objetivo de entender melhor o desenvolvimento dela no presente, ou seja, a história não é simples relato de fatos passados, mas análise dos acontecimentos que contribuíram para 0 surgimento de nossas atuais condições de vida (HOBSBAWN, 1998, p. 243).

0 revisionismo neonazista se baseia em teorias que tentam comprovar a inexistência do Holocausto, através de depoimentos de alguns "sobreviventes" do holocausto, como o historiador Robert Faurisson, que sobreviveu a sua passagem por um campo de concentração e, baseado nisso, afirma a não existência das câmaras de gás. Ora, é sabido que havia campos de concentração com diferentes práticas e programas, os quais recebiam indivíduos considerados mais ou menos perigosos. 0 fato de não ter existido câmara de gás em um campo de concentração específico não invalida a existência, notoriamente sabida, dessas câmaras em outros campos. Além disso, várias outras pessoas, também sobreviventes do Holocausto, relatam práticas e experimentos que fizeram parte de suas experiências. Esses relatos orais não poderiam ser considerados menos dignos de nota do que aquele feito por Robert Faurisson e que é utilizado na atualidade pelos movimentos neonazistas contemporâneos. Ainda nesse sentido, embasado no Relatório Leutcher, o grupo Valhalla 88 afirma: "Também não há prova alguma de que tenha existido qualquer política de extermínio, ordem oral ou por escrito de genocídio aos Judeus" (66 PERGUNTAS..., 2012). No sentido de negar a existência das câmaras como modo de extermínio, os membros do Valhalla 88 
chegam a afirmar que o gás ziklon-b (à base de cianureto) era usado como pesticida, para pulverizar pulgas e carrapatos, devido às péssimas condições sanitárias dos campos de concentração. Em outros casos, encontramos a própria negação da própria da existência das câmaras de gás nos campos durante a administração nazista:

[...] As câmaras de gás foram na verdade construídas por soviéticos e americanos após a tomada dos campos de concentração, e construídas de maneira absolutamente impossíveis para realização de qualquer extermínio e estão repletas de erros gritantes e patéticos [...] (66 PERGUNTAS..., 2012).

Essa onda de negação do Holocausto é uma tentativa de absolver o nazismo para que ele não seja mal encarado, de forma a novamente atrair outras pessoas para a causa. Livrando-se do peso de seis milhões de mortos, o nazismo, em uma nova roupagem, voltaria a atrair as pessoas. Os problemas sociais, a falta de investimento na educação, os grandes latifúndios no norte e nordeste do Brasil, que não permitem o desenvolvimento dessas regiões, ocasionando as migrações para sul e sudeste, a concorrência do mercado de trabalho, enfim, todas as dificuldades de sobreviver no mundo trazem insegurança às pessoas, gerando medo e preocupação com o futuro são pontos fortes de manipulação desta ideologia. Com as crises aumentando, algumas pessoas buscam uma alternativa ou uma ideologia para se agarrar.

\section{CONSIDERAÇÕES FINAIS}

As questões raciais, que são abordadas pelo grupo Valhalla 88, passam por diversas vertentes do pensamento racial, questão amplamente discutida por especialistas hoje no mundo e também por diferentes movimentos sociais de ação afirmativa. No entanto, os critérios biológicos de crença em uma "pureza racial" não conseguem ser defendidas com êxito desde 1948, quando descobriu-se que as várias etnias existentes no mundo partilham de uma estrutura de DNA rigorosamente semelhante. As diferenças existentes entre os diversos grupos sociais passam a ser encaradas por meio de outras explicações, baseadas em argumentos históricos, geopolíticos e culturais. Nesse sentido, o discurso do Valhalla 88 parece desconectado com a maioria das pesquisas do campo da biologia, área em que ancoram seu argumento. A própria declaração em prol de um grupo homogêneo racial é, nesse sentido ilusória.

Além disso, o grupo Valhalla 88 não parece ter um projeto político definido. Em seus textos, é possível verificar uma mistura, também não muito homogênea, 
sobre diversas concepções de capitalismo, compreensões de mundo, do que é raça e do que significa ser um nacional-socialista. Em parte, isso se deve à relativa dificuldade que o grupo Valhalla 88 deve enfrentar ao discutir um programa nacional-socialista para um país que compreende centenas de grupos étnicos, reunidos em uma pluralidade de sistemas religiosos e formados por diferentes nacionalidades e matrizes culturais.

A defesa de uma homogeneização em termos raciais e culturais seria, no mínimo, uma tarefa extremamente árdua em um país marcado pela pluralidade como o Brasil. Em primeiro lugar, para que fosse possível a realização desse grande plano, seria necessário expulsar, pelo menos, a maioria da população do país, que rapidamente combateria as propostas por eles levantadas. Em segundo lugar, para que isso fosse possível, o grupo teria que sair do anonimato em um momento em que suas crenças seriam facilmente enquadrados como racismo e crime de ódio pela legislação brasileira.

Contudo, a possibilidade desses ideais se concretizarem politicamente no Brasil não deve ser completamente subestimada. 0 discurso inflamado e perigoso que os neonazistas utilizam podem influenciar diversos setores da população civil e fazer com que avanços importantes no que diz respeito a políticas públicas e aos direitos de minorias étnicas e políticas passem a ser contestados pelo avanço do conservadorismo, que se reinventa historicamente, sobretudo em momentos de crises econômicas. Nesse sentido, engana-se aquele que acredita que os grupos neonazistas e ultraconservadores são passageiros e não oferecem risco à sociedade brasileira.

Prova disso é o fato de presenciarmos, na atualidade, o crescente aumento dos partidos de extrema direita na Europa, como a Frente Nacional, de Marine Le Pen, a Aurora Dourada, na Grécia, o Svoboda, na Ucrânia. Também no Brasil, parlamentares auto intitulados como conservadores, como por exemplo Jair Bolsonaro e Marcos Feliciano, que defendem abertamente discursos homofóbicos têm ganhado grande projeção no cenário político. Em termos midiáticos, pastores como Silas Malafaia, também se posicionam de maneira a contestar os direitos de minorias sexuais no país. Por fim, neste ano que completa 50 anos do golpe militar, vemos uma disputa pela memória sendo travada entre torturados e torturadores, além de uma série de discursos, publicados principalmente nas redes sociais, pedindo o retorno do governo militar. 


\section{REFERÊNCIAS}

66 PERGUNTAS e respostas sobre o holocausto. Valhalla88. Disponível em: $<$ http://www.nuevorden.net/portugues/valhalla88_7.html >. Acesso em: 15 set. 2012.

ALGUMAS considerações sobre raça e racismo. Valhalla88. Disponível em: $<$ http://www.nuevorden.net/portugues/valhalla88_3.html >. Acesso em: 9 jun. 2012.

ARENDT, Hannah. Origens do totalitarismo. São Paulo: Companhia das Letras, 1989.

BARBOSA, Jefferson Rodrigues. Integralismo e ideologia autocrática chauvinista regressiva: crítica aos herdeiros do sigma. Marília, 2012. Tese (Doutorado) Programa de Pós-Graduação em Ciências Sociais - Faculdade de Filosofia e Ciências, Universidade Estadual Paulista - UNESP, Marília, 2012.

CALDEIRA NETO, Odilon. Breves reflexões sobre o uso da Internet em pesquisas historiográficas. Revista Eletrônica Boletim do Tempo, Rio de Janeiro, ano 4, n. 20, 2009. Disponível em: <http://www.tempopresente.org > . Acesso em: 10 ago. 2012.

CALDEIRA NETO, Odilon. Integralismo, neointegralismo e antissemitismo: entre a relativização e o esquecimento. 2011. 234 f. Dissertação (Mestrado em História). Universidade Estadual de Maringá: Maringá, 2011.

COSTA, Marcia Regina. Os carecas do subúrbio: caminhos para o nomadismo moderno. São Paulo: Musa, 2000.

DARWIN, Charles. A origem das espécies e a seleção natural. Curitiba: Hemus, 2000 .

DIAS, Adriana Abreu Magalhães. Os anacronautas do teutonismo virtual: uma etnografia do neonazismo na Internet. Campinas: Unicamp, 2007.

DIWAN, Pietra. Raça pura: uma história de eugenia no Brasil e no mundo. São Paulo: Contexto, São Paulo, 2011.

G00DRICK-CLARKE, Nicholas. Sol Negro: cultos arianos, nazismo esotérico e políticas de identidade. São Paulo: Madras, 2004.

HERF, Jeffrey. O modernismo reacionário. Campinas: Ed. Unicamp; São Paulo: Ensaio, 1993. 
HOBSBAWM, Eric. 0 Presente como história. In: HOBSBAWM, Eric. Sobre história . São Paulo: Companhia das Letras, 1998.

LINHAS gerais. Valhalla88. Disponivel em: <http://www.nuevorden.net /portugues /valhalla88_7.html> . Acesso em: 15 set. 2012.

LOPES, Luiz Roberto. Do terceiro Reich ao novo nazismo. Porto Alegre: Ed. UFGRS, 1992.

MUNANGA, Kabengele. Uma abordagem conceitual das noções de raça, racismo, identidade e etnia. In: SEMINÁRIO NACIONAL DE RELAÇÕES RACIAIS E EDUCAÇÃO, 3., 2003, Rio de Janeiro. Palestra... Rio de Janeiro, 2003.

0 NACIONAL socialismo é de direita. Valhalla88. Disponivel em: $<$ http://www.nuevorden.net /portugues /valhalla88_7.html >. Acesso em: 15 set. 2012.

PROPAGANDA do futuro para o nacional socialismo Valhalla88. Disponível em: $<$ http://www.nuevorden.net /portugues /valhalla88_14.html>. Acesso em: 15 set. 2012.

RELACIONANDO-SE com seu meio. Valhalla88. Disponível em: $<$ www.nuevorden. net/portugues/valhalla88_8.html>. Acesso em: 9 jun. 2012.

SALEM, Helena. As tribos do mal: o neonazismo no Brasil e no mundo. São Paulo: Atual, 1995.

SALVE 0 ano zero! A revolução nacional socialista na prática Valhalla88. Disponível em: <http://www.nuevorden.net/portugues/valhalla88_15.html>. Acesso em: 15 set. 2012.

SALVE 0 ano zero! A revolução nacional socialista na prática Valhalla88. Disponivel em: <http://www.nuevorden.net/portugues/valhalla88_15.html > . Acesso em: 15 set. 2012. 2012i

VALHALLA $88 . \quad$ Disponível em: <http://www.nuevorden .net/portugues/valhalla88.html> . Acesso em: 9 jun. 2012. 